\title{
Sequential coherence as a determinant of open innovation: A case study on a Sri Lankan fintech solution
}

\author{
Shanta R Yapa \& R Senathiraja \\ Faculty of Management \& Finance, University of Colombo, Sri Lanka
}

\begin{abstract}
Open innovation is a popular strategy to accelerate innovations among business firms. However, open innovation does not always increase innovation performance. Arguments in extant literature in respect of the relationship between open innovation practices and innovation performance are inconsistent and inconclusive. Most existing theories have an internal focus and therefore fall short of explaining why some firms succeed in open innovation initiatives and why others fail. Open innovation is about knowledge flows. To understand how boundary conditions influence knowledge flows we conducted a detailed qualitative inquiry on an open innovation initiative of a software firm where a leading university and a private commercial bank participated as the knowledge partner and commercialization partner respectively in developing an award winning fintech solution. Analysis of data revealed that ability and willingness of teacher firm to share knowledge and also the ability and preparedness of student firm to acquire knowledge facilitated knowledge flows between the open innovation partner firms. We bundled those factors and named as sequential coherence. We trust that our findings bridge a gap in open innovation literature. These findings could be generalized through a large sample covering many other industry sectors. Managerial implications of the finding is that ability to scan the entire chain of knowledge flow across boundaries and taking corrective measures for any bottlenecks or hindrances observed can bring better results from open innovation initiatives. Further, sequential coherence leads to multiple research opportunities in furthering our knowledge in open innovation.
\end{abstract}

Keywords - Open innovation, innovation performance, knowledge flow, boundary conditions, sequential coherences 


\section{Introduction}

The increasing propensity of firms to work across their traditional boundaries of operations has been captured as Open innovation (OI) (Mina et al, 2014). Openness is a strategy (Chesbrough, 2017) and a trend in innovation management (Lopez \& Carvalho, 2018). OI has attracted wide academic attention (Kim et al, 2015). OI encourages organizations to open up their processes to harness external knowledge to accelerate internal innovations and also to use external paths in early commercialization of them (Chesbrough, 2003). Although the importance of acquiring external knowledge is widely accepted how the knowledge flow happens is little understood (Lakemond et al, 2016). Far less is known about with whom to partner in acquiring external knowledge (Lane \& Lubatkin, 1998). Why OI does not always bring higher innovation performance is not adequately addressed in existing literature (Yapa et al, 2018). Many firms struggle to harness value from OI initiatives (Salter et al, 2015; Lee \& Shin, 2015) as they fail to engage external actors (Dahlander \& Piezunka, 2014). Challenges firms face involving external actors in OI have become a popular area for research (Foss et al, 2011; Afuah \& Tucci, 2012; Felin \& Zenger, 2014; Hossain \& Anees-ur-Rehman, 2016). The rationale of an organization to select the best partner organization among multiple candidates possessing the required knowledge cannot be explained by existing theories (West et al, 2006; Rusanen, 2013; Von Krogh et al, 2018).

The objective of this paper is to present our findings from a qualitative inquiry we undertook to understand how knowledge flows through organizational boundaries in open innovation initiatives. Therefore, we frame the research problem as "How do boundary conditions influence performance of OI initiatives?" This addresses a gap in literature. This enables us to answer why OI initiatives lead to varying levels of innovation performance. Open innovation demands permeability of organizational boundaries (Dahlander \& Gann, 2010). Although OI is conceptualized as knowledge inflows and outflows at the level of organizational boundary most research work lacks focus on individuals involved in OI (Bogers et al, 2018). Managers and academics lack a proper understanding of the mechanisms involving the boundaries of the innovation process (Enkel et al, 2009). Brunswicker \& Vanhaverbeke (2015) suggest that research on open innovation should investigate the interrelation between boundary conditions and a firm's nature of openness. The boundary can be between partner firm and the lead 
firm or between internal departments of any organization be it the lead firm or a partner firm. Our findings will further enhance the understanding of factors influencing innovation performance in OI.

\section{Literature review}

Despite its growing popularity research is divided on whether organizations can benefit from OI (Lauritzen \& Karafyllia, 2018).Inconsistent arguments and inconclusive results appear in extant literature in respect of the relationship between OI and innovation performance (Yapa et al, 2017; Caputo et al, 2016; Cheng \& Shiu, 2015; Bengtsson et al, 2015). Open innovation is a multifaceted phenomenon (Randhawa, 2016) that demands understanding across various perspectives and levels of analysis (Bogers et al, 2017). In respect of determinants, processes and outcomes of OI, the multi-level framework introduced by Chesbrough and Bogers (2014) suggests examining the emerging perspectives within the organization, outside the organization, between organizations or in the broader context of industries.

Popular theories and variables used to understand OI include absorptive capacity (Cohen \& Levinthal, 1990; Murovec \& Prodan, 2009; De Zubielqui et al, 2016 and Matusik \& Heely, 2005), organizational inertia (Huang et al, 2013; Godkin, 2010; Chesbrough, 2006; Amabile et al, 1996; Matthyssens et al, 2006; Nijssen et al, 2006), search depth and breadth (Laursen \& Salter, 2006; Cruz-González et al, 2015; Garriga et al, 2013; Greco et al, 2016), cognitive distance (Inaun \& Schenker-Wicki, 2011; Gulati, 1995; Wuytz et al, 2005; Nooteboom, 2000; Nooteboom et al, 2007), ambidexterity (March, 1991; Tushman \& O'Reilly, 1996; Andriopoulos \& Lewis, 2009; Ferrari, 2011) and in-bound and out-bound OI practices (Enkel et al, 2009; Bianchi et al, 2015; West \& Bogers, 2014; Fernandes et al, 2017; Popa et al, 2017). However, these theories mainly focus on internal factors and they do not adequately explain OI practices and differences in innovation performance (Cheng \& Huizing, 2014; Bengtsson et al, 2015).

Harnessing value from OI initiatives has become a challenge for many firms (Salter et al, 2014; Lee \& Shin, 2015) as they fail to engage external actors (Dahlander \& Piezunka, 2014). The interface between respective stakeholders is an important study object in boundary-crossing innovation activity (Hargrave \& van de Van, 2006; Geels, 2004; Bogers et al 2017). Challenges firms face involving external actors in OI have become a popular area for research (Foss et al, 
2011; Afuah \& Tucci, 2012; Felin \& Zenger, 2014; Hossain \& Anees-urRehman, 2016). Lane \& Lubatkin (1998) emphasize the importance of examining with whom a firm should partner in acquiring new knowledge.Open innovation goes beyond the boundaries of the focal firm (Munir et al, 2018; Powell et al, 1996) and recent publications have persistently stressed the necessity of understanding the organizational and contextual factors that moderate the relationship between OI and innovation performance (Bengtsson et al, 2015). Therefore, our study on boundary conditions and knowledge flow is justifiable.

\section{Methodology}

We used the case study approach in looking for a new explanation for the relationship between open innovation and innovation performance. Merriam (1988) emphasized that there is no standard format for reporting case study research. Some case studies generate theory, some describe cases and others are analytical in nature (Creswell, 1998). Yin (1989) suggests that a case study can either be a single case study or a multiple case. Similarly, a case study can either be a holistic (single unit of analysis) or embedded (multiple units of analysis). Lincon \& Guba (1985) suggest that a substantive case report should include the explication of the problem, a comprehensive description of the context, detailed transactions or processes observed, salience and outcomes of the inquiry or the lessons learned. Stake (1995) outlines case study steps as outlining a vignette, identification of the issue, purpose and method of study, extensive description of case and context, presentation of issues, presenting assertions and an experiential note with a closing vignette. OI practices are popular among business organizations in Sri Lanka (Yapa \& Senathiraja, 2017). However, OI practices of the software industry in Sri Lanka show varying levels of innovation performance (Yapa et al, 2018). We selected an OI initiative of a Sri Lankan software firm in developing an award winning fintech solution as a case study. Extensive discussions and interviews were conducted with key employees of the selected firm and the OI partner firms to understand the factors and circumstances that facilitated innovation performance in respect of knowledge flows across the focal firms and OI partner firms. Readers should note that the real name of the organization is not divulged.

Zenith is a renowned software firm with a proven track record offering solutions in the domains of document management and digital enterprise automation. They were keen in entering 
the banking and financial software solutions sector as fintech solutions were gaining attention globally enabling customers to engage in online real time banking transactions easily.Zenith decided to design and develop an innovative fintech solution which can replace the traditional wallet with a digital wallet. Zenithalso realized the importance of acquiring external knowledge in the domain of secure electronic payments and also a partner to early commercialize the solution. They partnered with a local university as their inbound OI partner in acquiring new knowledge. Zenithalso selected a leading bank in the country and known for innovative digital solutions, as their outbound OI partner. The mobile wallet they jointly developed named eWalletwas adjudged as the best software solutions in the category of banking \& financial services at the National Best Quality Software Awards. The product also represented Sri Lanka at the Asia Pacific ICT Alliance awards 2018 and won a merit award outperforming 15 other economies in the region. The founder CEO of Zenith had this to say when asked about the secret of success.

Identifying the right partners is a very important activity in open innovations. We had many universities in the mind among whom we had to select the most appropriate one. Similarly, we had many options in selecting a bank as the commercialization partner.After a careful evaluation of the options, we selected the best known local university for software engineering as the knowledge partner. Fortunately, there were several academics with adequate exposure in to secure payments, information security and digital forensics. Common interests we shared pushed the project forward smoothly. Similarly, we partnered with the right bank which had the passion to innovate with a dire necessity to penetrate the market. When we described the digital wallet they readily accepted to partner with us. There again we assigned the right people from our end to work with the employees of our partner firms. Zenith employees were aware of the challenges in the project as they had to learn not only banking but also accounting and regulatory frameworks. Their preparedness to learn and share made it a success. We successfully concluded the open innovation initiative by introducing the best banking innovation in the country and also bringing glory and fame to the country winning an international award at the Asia Pacific ICT Alliance awards.

This is how the Chief Operating Officer of the company explained the situation. Acquiring the required knowledge from another organization is not something like you connect a pipe and open the 
valve so that knowledge flows. People who do belong to various ranks from the organizations take part in the process. Their passion and motivation levels may vary. Out of many potential employees of the knowledge partner the employees assigned from our end know the most appropriate ones to interact with and get the project going. We look for knowledge that is not easily found in books, journals or in the web. More than selecting the person with the best knowledge the one who has the desire to share and the right capability can make a big difference. This is very important as knowledge transfer does not end with one conversation. You got to interact regularly as the learner absorbs and builds new knowledge gradually like the way a wall is constructed by placing bricks one on another.

We had extensive discussions with key people from Zenith, their partner university and their partner bank. Zenith had to play the role as a student firm in acquiring new knowledge and also to act as the teacher firm in transferring knowledge to their commercialization partner. A comprehensive analysis of interview results revealed that the ability and the willingness of the employees of the teacher firm to share knowledge and the ability and preparedness of the employees of the student firm for learning are the factors influencing the knowledge flow. We bundle those factors together and describe as sequential coherence.

\section{Findings and discussion}

Wedefine sequential coherence as the reciprocal result of the push and pull effects by individuals of a teaching firm and the learning firm respectively that enables knowledge to flow across boundary of firms. We argue that sequential coherence can be measured through the ability and willingness to teach by the teacher firm participants and the ability and readiness to learn by the participants of the student firm as we observed through the qualitative study done. Sequential coherence can explain the relationship between OI initiatives and innovation performance. Much of the inter-organizational learning research use absorptive capacity which assumes a firm can equally learn from any other firm (Lane \& Lubatkin, 1998). We suggest that sequential coherence enables an organization to make use of its absorptive capacity. The boundary of firms become more porous with OI processes and increased interaction with external actors (Litchtenthaler, 2009). Sequential coherence focuses on the boundary conditions required for smooth cross border flow of knowledge and technology in both inbound and outbound OI practices. It focuses not only the ability but also the willingness of both the transferor and the recipient of 
knowledge. More than a measure of internal abilities, sequential coherence focuses on boundary conditions.

Purposive management of knowledge flows across boundaries is necessary in OI (Chesbrough \& Bogers, 2014; Lakemond et al, 2016) and we argue that sequential coherence can explain and ensure a smooth knowledge flow. Managers should carefully examine sequential coherence between the lead firm of OI and each partner firm to achieve the expected innovation performance. As the strength of a chain is defined and constrained by the strength of its weakest link, sequential coherence of each boundary in the knowledge flow matters in ensuring a smooth flow of knowledge. It is through regular scans of the chain of knowledge flow managers can identify any drawbacks, bottlenecks and hindrances to take corrective action. Firm A being the lead firm cooperates with firm B as inbound OI partner to access knowledge. Sequential coherence between firm A and firm B matters in ensuring the knowledge flow happens. Similarly, firm A works with firm $\mathrm{C}$ as the outbound OI partner where firm $\mathrm{C}$ will assist firm A to early commercialize their innovations. The sequential coherence between firm $\mathrm{A}$ and firm $\mathrm{C}$ is important to ensure the knowledge flow to achieve the desired innovation performance. We argue that any hindrance of sequential coherence between firms may affect innovation performance.

Absorptive capacity is considered as a critical resource that depends on the prior knowledge of a firm and determines the firm's innovative capabilities (Dell'Anno et al, 2015). Nonaka \& Takeuchi (1995) describe knowledge as the result of the interaction between the actors; the transferor and the recipient. We argue that in order to transfer knowledge both the ability and willingness of the transferor and recipient will matter. In this context, sequential coherence compliments absorptive capacity in acquiring knowledge.Internal R\&D capabilities are indispensable in effectively exploiting external knowledge (Cohen \& Levinthal, 1989; Vanhaverbeke \& Cloodt2014). It is important to understand the internal organization of the innovation process which determines diffusion and exploitation of technical knowledge within the organization (Noteboom et al, 2007: Levinthal \& March, 1993; Argyres \& Silverman, 2004). Lakemond et al (2016) describe the importance of firm's choice of knowledge governance in innovation performance. Bogers et al (2017) emphasize the importance of the roles played by individuals who are assigned with various tasks in $\mathrm{OI}$ in ensuring innovation performance. 
Heath and Staudenmaier (2000) describe that in accomplishing work, organizations should motivate employees so that their goals are aligned (the agency problem) and should organize the individuals so that their actions are aligned (the coordination problem).

We argue that sequential coherence can be considered as an add-on to absorptive capacity to better understand the knowledge flow from one person to another across boundaries in organizations in OI partner firms, departments and work teams. In each point of knowledge transfer the push and pull effect created by the willingness and ability of the participant from teacher firm and the ability and preparedness of the participant from the student firm impact the result. By examining and influencing the degree of sequential coherence practicing managers may influence innovation performance in OI initiatives. Vanhaverbeke \& Cloodt (2014) explain that absorptive capacity explains only the inbound OI process and it does not pay attention to outbound OI. Sequential coherence can bridge this gap as it addresses seamless knowledge transfer across the value chain from inbound OI, internal knowledge transfer and outbound OI. In this regard, the unit of analysis in using sequential coherence may be the organization or the entire network of OI relationships.
OI is an inherently dynamic process that demands research to incorporate dynamic elements (Appleyard \& Chesbrough, 2017). We argue that sequential coherence is a dynamic measure capable of influencing innovation performance in OI initiatives. Why do some open innovation initiatives lead to higher innovation performance and some fail (Cheng \& Huizing, 2014; Bengtsson et al, 2015)? Firm A succeeds with firm B in an OI initiative whereas a similar initiative firm A undertakes with firm C fails. If we examine only an ability that is pertaining to firm A we cannot explain why one initiative failed and the other succeeded. We suggest that sequential coherence can explain this and it is a precondition for absorptive capacity to work in favor of an organization.

Sequential coherence ensures that knowledge will flow smoothly from teacher firm to student firm in an unbroken manner. This transmission may happen through people via discussions, presentations and interactive learning (Kogut \& Zander, 1996) and also through products and processes. Higher social interaction between firms facilitated through multiple ties enhances knowledge acquisition (Yli-Renko et al, 2001). Naqshbandi (2016) emphasizes the importance of managers to keep in touch with people from different firms in ensuring OI performance. If we compare 
knowledge flow across partner firms with the current flow of an electric circuit where components are considered as different firms, sequential coherence describes the soldered joints between various components. It is also similar to the cable lugs used in connecting different components. Capacity, performance and specifications of individual components will be of no use if we fail to make the proper connections. As an engineer quickly scans all the soldered joints between different components he assembled in a printed circuit board when it is found not working properly, a manager can examine the knowledge flow at boundaries when things are not moving in OI initiatives as expected. We argue that sequential coherence enables knowledge fusion.

There is growing interest on assessing OI at a more micro level than the organization (Bogers et al, 2018; Du et al, 2014; Salter et al, 2015; Dahlander et al, 2016; Ahn et al, 2017). However, individual level factors remain relatively ill understood (Bogers et al, 2017). Most research studies on OI have neglected the human aspect of it (Gassman et al, 2010; West et al, 2014). Salter et al (2014) emphasize the challenges faced by employees in OI initiatives. $R \& D$ employees need to allocate time to innovate within and also outside the firm (Dahlander et al,
2016).We argue that higher sequential coherence leads to improved innovation performance in OI initiatives. Practicing managers may use sequential coherence in influencing innovation performance in open innovation initiatives by taking action to address the four areas highlighted namely willingness and ability of participants from teacher firm and the preparedness and ability of student firm participants. OI research studies show that when adopting OI strategies organizations benefit differently and the reasons for these differences are not explained (Saebi et al, 2015). We believe that our findings support extant literature and will increase the understanding on OI. We propose to test the new determinant of sequential coherence with a larger sampleusing quantitative research methodology for generalizing it.

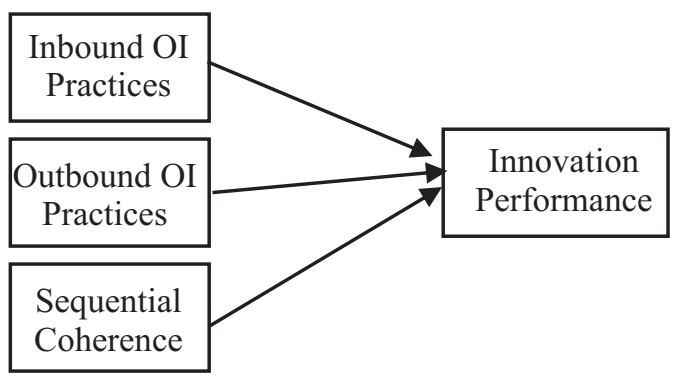

Figure 1 - Suggested conceptual model for a quantitative study

Willingness and the ability of teacher firm employees to share knowledge and the preparedness and the ability of the student firm to acquire knowledge from 
the teacher firm are the measurable dimensions we can identify in operationalizing the construct of sequential coherence.

Further, it will be interesting to understand how sequential coherence can address issues of cognitive distance, search depth, organizational inertia and ambidexteritythe regularly used variables in explaining innovation performance, through further research. For an example, we may test whether a high degree of sequential coherence influence search depth in OI initiatives. Whether attempting to engage in both inbound and outbound O I simultaneously may lead to waste of resources and efforts will be another area to be researched from a sequential coherence perspective. How sequential coherence can address stickiness of knowledge (Szulanski, 1995; Szulanski, 2002) will also be an interesting area for further research. Further, we may examine whether the opportunity for participants from teacher firms to learn from the student firm enhances the knowledge flow from teacher firm to student firm. Finally, a major area future researchers may explore is to study how individual factors such as attitudes, personality, perception and motivation of participants affect sequential coherence.

\section{References}

Afuah, A., \& Tucci, C. L. (2012). Crowdsourcing as a solution to distant search. Academy of Management Review, 37(3), 355-375.

Ahn, J. M., Minshall, T., \& Mortara, L. (2017). Understanding the human side of openness: the fit between open innovation modes and CEO characteristics. $R \& D$ Management, 47(5), 727-740.

Amabile, T. M., Conti, R., Coon, H., Lazenby, J., \& Herron, M. (1996). Assessing the work environment for creativity. Academy of management journal, 39(5), 1154-1184.

Andriopoulos, C., \& Lewis, M. W. (2009). Exploitation-exploration tensions and organizational ambidexterity: Managing paradoxes of innovation. Organization Science, 20(4), 696-717. Appleyard, M.M., Chesbrough, H.W., (2017), The dynamics of open strategy: from adoption to reversion. Long Range Plan. 50, 310-321.

Argyres, N. S., \& Silverman, B. S. (2004). $\mathrm{R} \& \mathrm{D}$, organization structure, and the development of corporate technological knowledge. Strategic Management Journal, 25(8-9), 929-958.

Bengtsson, L., Lakemond, N., Lazzarotti, V., Manzini, R., Pellegrini, L., \& Tell, F. (2015). Open to a select few? Matching partners and knowledge content for open innovation performance. Creativity and innovation management, 24(1), 72-86.

Bianchi, M., Croce, A., Dell'Era, C., Di Benedetto, C. A., \& Frattini, F. (2015). 
Organizing for inbound open innovation: How external consultants and a dedicated R\&D unit influence product innovation performance. Journal of Product Innovation Management.

Bogers, M., Zobel, A.K., Afuah, A., Almirall, E., Brunswicker, S., Dahlander, L., Frederiksen, L., Gawer, A., Gruber, M., Haefliger, S. and Hagedoorn, J.(2017). The open innovation research landscape: Established perspectives and emerging themes across different levels of analysis. Industry and Innovation, 24(1), 8-40.

Bogers, M., Foss, N. J., \& Lyngsie, J. (2018). The "human side" of open innovation: The role of employee diversity in firm-level openness. Research Policy, 47(1), 218-231.

Brunswicker, S., \& Vanhaverbeke, W. (2015). Open innovation in small and medium-sized enterprises (SMEs): External knowledge sourcing strategies and internal organizational facilitators. Journal of Small Business Management, 53(4), 1241-1263.

Caputo,M., Lambert, E., Cammarano, A., Michelino, F. (2016). Exploring the impact of open innovation on firm performance. Management Decisions. 54, 1788-1812.

Cheng, C. C., \& Huizingh, E. K. (2014). When is open innovation beneficial? The role of strategic orientation. Journal of Product Innovation Management, 31(6), 1235-1253.

Cheng, C. C., \& Shiu, E. C. (2015). The inconvenient truth of the relationship between open innovation activities and innovation performance. Management Decision, 53(3), 625-647.

Chesbrough, H. (2003). The logic of open innovation: managing intellectual property. California Management Review, 45(3), 33-58

Chesbrough, H. (2017). The Future of Open Innovation: IRI Medal Address The future of open innovation will be more extensive, more collaborative, and more engaged with a wider variety of participants. Research Technology Management, 60(6), 29-35.

Chesbrough, H., \& Bogers, M. (2014). Explicating Open Innovation: Clarifying an Emerging Paradigm for Understanding Innovation,[w:] Open Innovation: New Frontiers and Applications, red. H. Chesbrough, W. Vanhaverbeke. J. West, Oxford: Oxford University Press.

Chesbrough, H. W. (2006). Open innovation: The new imperative for creating and profiting from technology. Harvard Business Press.

Cohen, W. M., \& Levinthal, D. A. (1990). Absorptive capacity: A new perspective on learning and innovation. Administrative science quarterly, 128152.

Creswell, J. W. (1998). Qualitative inquiry and research design: Choosing among five traditions.

Cruz-González, J., López-Sáez, P., NavasLópez, J. E., \& Delgado-Verde, M. (2015). Open search strategies and firm performance: The different moderating role of technological environmental dynamism. Technovation, 35, 32-45. 
Dahlander, L., \& Gann, D. M. (2010). How open is innovation?. Research policy, 39(6), 699-709.

Dahlander, L., O'Mahony, S., \& Gann, D. M. (2016). One foot in, one foot out: how does individuals' external search breadth affect innovation outcomes? Strategic Management Journal, 37(2), 280-302.

Dahlander, L., \& Piezunka, H. (2014). Open to suggestions: How organizations elicit suggestions through proactive and reactive attention. Research Policy, 43(5), 812-827.

De Zubielqui, G. C., Jones, J., \& Lester, L. (2016). Knowledge inflows from market and science based actors, absorptive capacity, innovation and performance - A study of SMEs. International Journal of Innovation Management, 20(06), 1650055.

Dell'Anno, D., \& Del Giudice, M. (2015). Absorptive and desorptive capacity of actors within university-industry relations: does technology transfer matter?. Journal of Innovation and Entrepreneurship, 4(1), 13.

Du, J., Leten, B., \& Vanhaverbeke, W. (2014). Managing open innovation projects with science-based and marketbased partners. Research Policy, 43(5), 828-840.

Enkel, E., Gassmann, O., \& Chesbrough, H. (2009). Open R\&D and open innovation: exploring the phenomenon. R\&d Management, 39(4), 311-316.

Felin, T., \& Zenger, T. R. (2014). Closed or open innovation? Problem solving and the governance choice. Research Policy, 43(5), 914-925.
Fernandes, S., Cesario, M., Barata, J.M. (2017). Ways to open innovation: Main agents and the sources in the Portuguese case. Technology in Society, 51, 153162.

Ferrary, M. (2011). Specialized organizations and ambidextrous clusters in the open innovation paradigm. European Management Journal, 29(3), 181-192.

Foss, N. J., Laursen, K., \& Pedersen, T. (2011). Linking customer interaction and innovation: The mediating role of new organizational practices. Organization Science, 22(4), 980-999.

Garriga, H., Von Krogh, G., \& Spaeth, S. (2013). How constraints and knowledge impact open innovation. Strategic Management Journal, 34(9), 11341144.

Gassmann, O., Enkel, E., \& Chesbrough, H. (2010). The future of open innovation. R\&dManagement, 40(3), 213-221.

Geels, F. W. (2004). From sectoral systems of innovation to socio-technical systems: Insights about dynamics and change from sociology and institutional theory. Research policy, 33(6-7), 897920.

Godkin, L. (2010). The zone of inertia: absorptive capacity and organizational change. The Learning Organization, 17(3), 196-207.

Greco, M., Grimaldi, M., \& Cricelli, L. (2016). An analysis of the open innovation effect on firm performance. European Management Journal, 34(5), 501-516.

Gulati, R. (1995). Social structure and alliance formation patterns: A 
longitudinal analysis. Administrative science quarterly, 619-652.

Hargrave, T. J., \& Van de Ven, A. H. (2006). A collective action model of institutional innovation. Academy of management review, 31(4), 864-888.

Heath, C., \& Staudenmayer, N. (2000). Coordination neglect: How lay theories of organizing complicate coordination in organizations. Research in organizational behavior, 22, 153-191.

Hossain, M., \& Anees-ur-Rehman, M. (2016). Open innovation: an analysis of twelve years of research. Strategic Outsourcing: An International Journal, 9(1), 22-37.

Huang, H. C., Lai, M. C., Lin, L. H., \& Chen, C. T. (2013). Overcoming organizational inertia to strengthen business model innovation: An open innovation perspective. Journal of Organizational Change Management, 26(6), 977-1002.

Inauen, M., \& Schenker-Wicki, A. (2012). Fostering radical innovations with open innovation. European Journal of Innovation Management, 15(2), 212-231.

Kim, N., Kim, D. J., \& Lee, S. (2015). Antecedents of open innovation at the project level: empirical analysis of Korean firms. $R \& D$ Management, 45(5), 411-439.

Kogut, B., \& Zander, U. (1996). What firms do? Coordination, identity, and learning. Organization science, 7(5), 502-518.

Lakemond, N., Bengtsson, L., Laursen, K., \& Tell, F. (2016). Match and manage: the use of knowledge matching and project management to integrate knowledge in collaborative inbound open innovation. Industrial and Corporate Change, 25(2), 333-352.

Lane, P. J., \& Lubatkin, M. (1998). Relative absorptive capacity and inter organizational learning. Strategic management journal, 19(5), 461-477.

Lauritzen, G. D., \& Karafyllia, M. (2019). Perspective: leveraging open innovation through paradox. Journal of Product Innovation Management, 36(1), 107121.

Laursen, K., \& Salter, A. (2006). Open for innovation: the role of openness in explaining innovation performance among UK manufacturing firms. Strategic management journal, 27(2), 131-150.

Lee, B., Cho, H. H., \& Shin, J. (2015). The relationship between inbound open innovation patents and financial performance: evidence from global information technology companies. Asian Journal of Technology Innovation, 23(3), 289-303.

Levinthal, D. A., \& March, J. G. (1993). The myopia of learning. Strategic management journal, 14(S2), 95-112.

Lichtenthaler, U. (2009). Outbound open innovation and its effect on firm performance: examining environmental influences. R\&d Management, 39(4), 317-330.

Lincoln, Y. S., \& Guba, E. G. (1985). Naturalistic inquiry (Vol. 75). Sage.

Lopes, A.P.V.B.V. \& Carvalho, M.M.D. (2018). Evolution of the open innovation paradigm: Towards a contingency conceptual model. Technological Forecasting \& Social Change, 132, 284-298. 
March, J. G. (1991). Exploration and exploitation in organizational learning. Organization science, 2(1), 71-87.

Matthyssens, P., Vandenbempt, K., \& Berghman, L. (2006). Value innovation in business markets: Breaking the industry recipe. Industrial Marketing Management, 35(6), 751-761.

Matusik, S. F., \& Heeley, M. B. (2005). Absorptive capacity in the software industry: Identifying dimensions that affect knowledge and knowledge creation activities. Journal of Management, 31(4), 549-

Mina, A., Bascavusoglu-Moreau, E., \& Hughes, A. (2014). Open service innovation and the firm's search for external knowledge. Research Policy, 43(5), 853-866.

Merriam, S. B. (1988). Case study research in education: A qualitative approach. Jossey-Bass.

Munir, H., Linaker, J., Wnuk, K., Runeson, P., Regnell, B. (2018) Open innovation using open source tools: A case study at Sony Mobile. Empr Software Engineering, 23: 186-233.

Murovec, N., \& Prodan, I. (2009). Absorptive capacity, its determinants, and influence on innovation output: Cross-cultural validation of the structural model. Technovation, 29(12), 859-872.

Naqshbandi, M. M. (2016). Managerial ties and open innovation: examining the role of absorptive capacity. Management Decision, 54(9), 2256-2276.

Nijssen, E. J., Hillebrand, B., Vermeulen, P. A., \& Kemp, R. G. (2006). Exploring product and service innovation similarities and differences. International Journal of Research in Marketing, 23(3), 241-251.

Nonaka, I., \& Takeuchi, H. (1995). The Knowledge Creating. New York, 304.

Nooteboom, B. (2000). Learning by interaction: absorptive capacity, cognitive distance and governance. Journal of management and governance, 4(1-2), 69-92

Nooteboom, B., Van Haverbeke, W., Duysters, G., Gilsing, V., \& Van den Oord, A. (2007). Optimal cognitive distance and absorptive capacity. Research policy, 36(7), 1016-1034.

Popa, S., Soto-Acosta, P., \& MartinezConesa, I. (2017). Antecedents, moderators, and outcomes of innovation climate and open innovation: An empirical study in SMEs. Technological Forecasting and Social Change, 118, 134-142.

Powell, W. W., Koput, K. W., \& SmithDoerr, L. (1996). Interorganizational collaboration and the locus of innovation: Networks of learning in biotechnology. Administrative science quarterly, 116-145.

Randhawa, K., Wilden, R., \& Hohberger, J. (2016), A bibliometric review of open innovation: Ssetting a research agenda. Journal of Production \& Innovation Management. 33, 750-772.

Rusanen, H. (2013, January). Finding the right partners for innovation networks. In ISPIM Conference Proceedings ( $\mathrm{p}$. 1). The International Society for Professional Innovation Management (ISPIM). 
Saebi, T., \& Foss, N. J. (2015). Business models for open innovation: Matching heterogeneous open innovation strategies with business model dimensions. European Management Journal, 33(3), 201-213.

Salter, A., Criscuolo, P., \& Ter Wal, A. L. (2014). Coping with open innovation: responding to the challenges of external engagement in R\&D. California Management Review, 56(2), 77-94.

Salter, A., Ter Wal, A. L., Criscuolo, P., \& Alexy, O. (2015). Open for ideation: Individual - level openness and idea generation in R\&D. Journal of Product Innovation Management, 32(4), 488504.

Stake, R. E. (1995). The art of case study research. Sage.

Szulanski, G. (1995). Unpacking stickiness: An empirical investigation of the barriers to transfer best practice inside the firm. In Academy of Management Proceedings (Vol. 1995, No. 1, pp. $437-$ 441). Briarcliff Manor, NY 10510: Academy of Management.

Szulanski, G. (2002). Sticky knowledge: Barriers to knowing in the firm. Sage.

Tushman, M. L., \& O'Reilly, C. A. (1996). The ambidextrous organizations: Managing evolutionary and revolutionary change. California Management Review, 38(4), 8-30.

Vanhaverbeke, W., \& Cloodt, M. (2014). Theories of the firm and open innovation. New frontiers in open innovation, 256-278.

Von Krogh, G., Netland, T., \& Wörter, M. (2018). Winning With Open Process
Innovation. MIT Sloan Management Review, 59(2), 53-56.

West, J., \& Bogers, M. (2014). Leveraging external sources of innovation: a review of research on open innovation. Journal of Product Innovation Management, 31(4), 814-831.

West, J., \& Gallagher, S. (2006). Challenges of open innovation: the paradox of firm investment in open-source software. R\&dManagement, 36(3), 319-331.

Wuyts, S., Colombo, M. G., Dutta, S., \& Nooteboom, B. (2005). Empirical tests of optimal cognitive distance. Journal of Economic Behavior \& Organization, 58(2), 277-302.

Yapa, S. R. \& Senathiraja, R. (2017). Inbound open innovation: Whom to converge with and why? International Conference on the Humanities and the Social Sciences. ICHSS 2017 , University of Peradeniya, Sri Lanka.

Yapa, S. R., Senathiraja, R., \& Kauranen, I. (2018). Improving Innovation Performance by Convergence in Open Innovation: Evidence from Software Firms in Sri Lanka. Vidyodaya Journal of Management, 4(1).

Yli-Renko, H., Autio, E., \& Sapienza, H. J. (2001). Social capital, knowledge acquisition, and knowledge exploitation in young technology-based firms. Strategic management journal, 22(6-7), 587-613.

Yin, R. K. (1989). Case study research: Design and methods, revised edition. Applied Social Research Methods Series, 5. 